Marquette University

e-Publications@Marquette

Psychology Faculty Research and Publications

Psychology Department

$7-1-2012$

Memory Modulation in the Classroom: Selective Enhancement of College Examination Performance by Arousal Induced after Lecture

Kristy A. Nielson

Marquette University, kristy.nielson@marquette.edu

Timothy J. Arentsen

Fuller Theological Seminary

Accepted version. Neurobiology of Learning and Memory, Vol. 98, No. 1 (July 2012): 12-16. DOI. (C) 2012 Elsevier Inc. Used with permission. 


\title{
Memory Modulation In The Classroom: Selective Enhancement Of College Examination Performance By Arousal Induced After Lecture
}

\author{
Kristy A. Nielson \\ Department of Psychology and the Integrative Neuroscience \\ Research Center \\ Department of Neurology and the Center for Imaging Research, \\ Medical College of Wisconsin \\ Milwaukee, WI \\ Timothy J. Arentsen \\ Department of Clinical Psychology, Fuller Graduate School of \\ Psychology \\ Pasadena, CA
}

\begin{abstract}
Laboratory studies examining moderate physiological or emotional arousal induced after learning indicate that it enhances memory consolidation. Yet, no studies have yet examined this effect in an applied context. As such, arousal was induced after a college lecture and its selective effects were examined on later exam performance. Participants were divided into two groups who either watched a neutral video clip $(n=66)$ or an arousing video
\end{abstract}

Neurobiology of Learning and Memory, Vol 98, No. 1 (July 2012): pg. 12-16. DOI. This article is @ Elsevier and permission has been granted for this version to appear in e-Publications@Marquette. Elsevier does not grant permission for this article to be further copied/distributed or hosted elsewhere without the express permission from Elsevier. 
clip ( $n=70$ ) after lecture in a psychology course. The final examination occurred two weeks after the experimental manipulation. Only performance on the group of final exam items that covered material from the manipulated lecture were significantly different between groups. Other metrics, such as the midterm examination and the total final examination score, did not differ between groups. The results indicate that post-lecture arousal selectively increased the later retrieval of lecture material, despite the availability of the material for study before and after the manipulation. The results reinforce the role of post-learning arousal on memory consolidation processes, expanding the literature to include a real-world learning context.

Keywords: Memory consolidation, Arousal, Applied memory, Study techniques, Memory modulation

\section{I ntroduction}

Considerable research has been devoted to developing effective techniques to enhance learning and retention in the classroom environment. Such research has primarily focused on approaches that target encoding and retrieval effectiveness (see Willingham, 2008). Moreover, these approaches typically require students to acquire and apply new skills or study strategies. That is, they require the learner to change his or her approach to learning. Some of the strategies include studying in groups (」ohnson \& Johnson, 1983; Nastasi \& Clements, 1991), active learning (e.g., Cherney, 2008), focusing on key words (Reutzel \& Hollingsworth, 1988), using specific note-taking and review strategies that emphasize the encoding specificity principle (Kobayashi, 2006), maintaining congruence of encoding and retrieval conditions (Cassaday, Bloomfield, \& Hayward, 2002; Metzger, Boschee, Haugen, \& Schnobrich, 1979), and employing imagination (Cooper, Tindall-Ford, Chandler, \& Sweller, 2001; Leahy \& Sweller, 2005) or mnemonics (Atkinson et al., 1999; Carney \& Levin, 2002; Dretzke, 1993; Levin \& Levin, 1990; Peters \& Levin, 1986; Rummel, Levin, \& Woodward, 2003). Yet, some strategies are better than others (Butler \& Roediger, 2007; Rickards \& McCormick, 1988) and each strategy has limitations. Importantly, approaches that specifically target memory consolidation have been largely untested.

Memory consolidation, the foundation of memory storage, consists of a complex series of neurobiological processes that occur from seconds to days after the original learning (see McGaugh, 1990, 2000; Nielson \& Powless, 2007; Revelle \& Loftus, 1992; Torras-Garcia,

Neurobiology of Learning and Memory, Vol 98, No. 1 (July 2012): pg. 12-16. DOI. This article is @ Elsevier and permission has been granted for this version to appear in e-Publications@Marquette. Elsevier does not grant permission for this article to be further copied/distributed or hosted elsewhere without the express permission from Elsevier. 
Portell-Cortés, Costa-Miserachs, \& Morgado-Bernal, 1997).

Importantly, emotional and arousing events are known to be better recollected than neutral events, which is thought due at least in part to the influence of neural and hormonal responses to such events (LaBar \& Cabeza, 2006; McGaugh, 2000, 2004). Specifically, stressful and arousing events cause increased release of substances such as glucose, cortisol, and epinephrine (Dickerson \& Kemeny, 2004; McCarty \& Gold, 1981; McGaugh, 1990, 2000; Merali, Mcl ntosh, Kent, Michaud, \& Anisman, 1998; Piazza \& Le Moal, 1997), which have been repeatedly associated with memory modulation (e.g., Czech, Nielson, \& Laubmeier, 2000; LaBar \& Cabeza, 2006; McGaugh, 2000; Nielson, Czech, \& Laubmeier, 1999; Nielson \& Jensen, 1994; van Stegeren, Everaerd, Cahill, McGaugh, \& Gooren, 1998). These substances act, at least in part, by influencing amygdala function, which then modulates the memory consolidation processes (Adolphs, Tranel, \& Buchanan, 2005; Canli, Zhao, Brewer, Gabrieli, \& Cahill, 2000; Kensinger \& Corkin, 2004; McGaugh, 2004). Importantly, memory modulatory effects can be generated during or after learning. During learning, they can influence attention, encoding and consolidation. As such, emotional, arousing, or neurohumoral treatments have often been applied after learning to examine their isolated effects on the memory consolidation process.

A variety of post-learning treatments have demonstrated effectiveness for enhancing memory performance in human participants. These treatments include invasive approaches, such as moderate doses of norepinephrine (Southwick et al., 2002), epinephrine (Cahill \& Alkire, 2003), glucose (in older adults; Manning, Parsons, \& Gold, 1992), and nicotine (Colrain, Mangan, Pellett, \& Bates, 1992); and non-invasive treatments, such as moderate muscle tension (Nielson \& Jensen, 1994 (in older and young adults); Nielson, Radtke, \& Jensen, 1996), stress (Cahill, Gorski, \& Le, 2003), rewards (Nielson \& Bryant, 2005) and negative or positive emotional arousal induction (Nielson \& Bryant, 2005; Nielson \& Powless, 2007; Nielson, Yee, \& Erickson, 2005). For the effects produced by emotional arousal, the impact on memory performance is not dependent upon subjective response to the arousal (Nielson \& Meltzer, 2009) or semantic relatedness of the stimulus to the memoranda (Nielson \& Bryant, 2005; Nielson \& Meltzer, 2009; Nielson \& Powless, 2007; Nielson et al., 2005), but it can be mediated by emotion regulation traits and a 
predisposition towards arousal (Nielson \& Lorber, 2009). Furthermore, the manipulation of memory storage processes is time-dependent, but it can be effective even when delayed for a considerable time (e.g., $30 \mathrm{~min}$ ) after the original learning (Gold \& van Buskirk, 1975; McGaugh, 1966; Nielson \& Powless, 2007; Squire, 1986). While such treatments can enhance long-term retrieval (e.g., Nielson \& Jensen, 1994; Nielson \& Powless, 2007; Nielson et al., 1996, 2005), they typically impede immediate and short-term retrieval, likely because some aspects of memory consolidation require hours or days to complete (Kleinsmith \& Kaplan, 1963; Revelle \& Loftus, 1992; TorrasGarcia et al., 1997; Walker, 1958).

The existing studies on memory modulation in humans have commonly employed word lists or pictures as memoranda. While an experimentally sound method to examine learning and memory, performance on such tasks may not adequately index performance on learning and retention of more complex facts, concepts, or skills. Word list studies also may not provide enough ecological validity to assist in translating such approaches to classroom settings. Thus, the present study tested whether a post-learning arousal manipulation could enhance the delayed retrieval of lecture material in a college psychology course. Retrieval was tested two weeks later. Retrieval for material introduced during the lecture on the day of the manipulation was compared with retrieval for material presented prior to and subsequent to the manipulated lecture. It was hypothesized that students who were aroused soon after lecture would exhibit better exam performance for that material, relative to material presented on other lecture days.

\section{Materials and methods}

\subsection{Participants}

Undergraduates ( $n=156,33$ male) enrolled in a psychology course served as participants and all were present in class on each of the three study-relevant lecture days. Anyone who did not attend all three lectures or who chose not to stay to participate in the study opportunity was excluded from analyses ( $n=20$ total). The experiment was performed on two separate occasions in different

Neurobiology of Learning and Memory, Vol 98, No. 1 (July 2012): pg. 12-16. DOI. This article is (C) Elsevier and permission has been granted for this version to appear in e-Publications@Marquette. Elsevier does not grant permission for this article to be further copied/distributed or hosted elsewhere without the express permission from Elsevier. 
years with cohorts of similar size (i.e., cohort1 $n=73$ (37 control, 36 experimental), cohort2 $\mathrm{n}=63$ ( 29 control, 34 experimental)), but with the same course, lectures and exams. The procedures used were approved by the local IRB.

\subsection{Materials and procedures}

\subsubsection{Lecture material}

The last three lecture days of the semester in a cognitive psychology course were used for this experiment, which occurred two weeks prior to the final exam. All three lectures covered language as a primary topic, but each covered non-overlapping subtopics, constructs, theories, and key terms. The amount of material presented each day and length of lecture was comparable-the number of slides, constructs, and key words were controlled, and all subjects learned (and were tested) concurrently. The study manipulation involved only the second of the three lectures, providing a measure of memory performance for information presented on the manipulated day, as well as for the lectures day before and after the manipulation.

\subsubsection{Video manipulation}

The manipulated lecture was followed by an extra credit opportunity offered to the students that involved viewing and evaluating a video clip immediately after class. Extra credit for research participation and appropriate alternatives were offered as a regular part of the course; this was one opportunity for a portion of the total credit. Participants were randomly assigned to conditions. Those assigned to the control condition were taken to an adjacent room and shown a 3-min video clip of a documentary about the role of cardiovascular health in depression. Students assigned to the experimental (i.e., arousal) condition were simultaneously taken to another adjacent room and shown a 3-min video clip of live-action oral surgery. The videos were shown in previous studies to successfully distinguish arousal induction and memory enhancement by arousal (e.g. , Nielson \& Lorber, 2009). In both groups, students completed a brief survey about the video afterward; the survey was the same for each group. The survey included a 10-point Likert-type rating of (1) 
current mood (extremely negative to extremely positive), (2) current arousal state (not at all aroused to extremely aroused), and evaluations of the clip as ranging from "not at all" to "extremely", (3) unpleasant, (4) disgusting, and (5) interesting.

\subsubsection{Class performance measures}

Exam items considered were all 5-option multiple-choice questions worth one point each on a 100-point exam. For each of the three lecture days, seven questions were included on the final exam. The percentage correct for these sets of questions was used as the performance measure for each of the lecture days. No other course assignments, requirements or options differed between experimental groups. All questions on the exam were presented in quasi-random topical order. Additional performance scores evaluated for this study included the midterm exam score, the final exam score, and the total percentage of points achieved for the course.

\section{Results}

\subsection{Descriptive statistics}

Descriptive statistics for each participant group are presented in Table 1. The experimental groups did not differ by age. Video clip evaluation ratings showed experimental group differences in subjective evaluation of the clips, where the experimental group rated their clip (i.e., surgery) as more unpleasant, more disgusting and less interesting than the control group rated its documentary clip. Post-clip subjective ratings for mood and arousal also showed significant group differences, where the experimental group had significantly more negative mood state and greater feelings of subjective arousal than the control group. As a control measure, ratings were analyzed by ANOVA, showing no significant effects of cohort ( $p s>$.13) or Group interaction with cohort ( $p s>.12)$.

Table 1. Descriptive statistics by participant group (mean \pm SD).

Neurobiology of Learning and Memory, Vol 98, No. 1 (July 2012): pg. 12-16. DOI. This article is @ Elsevier and permission has been granted for this version to appear in e-Publications@Marquette. Elsevier does not grant permission for this article to be further copied/distributed or hosted elsewhere without the express permission from Elsevier. 


\begin{tabular}{|c|c|c|c|c|c|c|c|c|c|}
\hline & Age & $\begin{array}{l}\text { Post- } \\
\text { video } \\
\text { rating: } \\
\text { mood }\end{array}$ & $\begin{array}{l}\text { Post- } \\
\text { video } \\
\text { rating: } \\
\text { arousal }\end{array}$ & $\begin{array}{l}\text { Clip rating: } \\
\text { unpleasant }\end{array}$ & $\begin{array}{l}\text { Clip } \\
\text { rating: } \\
\text { disgust }\end{array}$ & $\begin{array}{c}\text { Clip } \\
\text { rating: } \\
\text { interesting }\end{array}$ & $\begin{array}{c}\text { Midterm } \\
\text { exam } \\
\text { total }\end{array}$ & $\begin{array}{l}\text { Final } \\
\text { exam } \\
\text { total }\end{array}$ & $\begin{array}{l}\text { Course } \\
\text { total \% }\end{array}$ \\
\hline Experimental & 20.09 & 5.11 & 7.60 & 6.57 & 6.94 & 5.60 & 70.9 & 69.0 & 79.9 \\
\hline $\begin{array}{l}n=70 \text { (56 } \\
\text { female) }\end{array}$ & (1.84) & (1.99) & (1.35) & $(2.80)$ & $(2.94)$ & $(2.40)$ & (10.9) & (11.4) & $(8.1)$ \\
\hline Control & 20.86 & 6.27 & 5.88 & 4.15 & 1.42 & 7.76 & 71.6 & 70.8 & 81.7 \\
\hline $\begin{array}{l}n=66 \text { (60 } \\
\text { female) }\end{array}$ & (3.97) & (1.34) & (1.28) & $(1.76)$ & $(0.75)$ & $(1.38)$ & (11.6) & (10.6) & $(6.8)$ \\
\hline $\mathrm{t}(134)=$ & 1.48 & -3.95 & 7.63 & 6.00 & 14.77 & 6.38 & 0.36 & 0.94 & 1.39 \\
\hline $\mathrm{p}$ & .14 & $<.001$ & $<.001$ & $<.001$ & $<.001$ & $<.001$ & .72 & .35 & .17 \\
\hline
\end{tabular}

\subsection{Course performance}

The experimental groups did not differ on the general course performance indicators (see Table 1). Specifically, there was no significant group difference on the midterm exam $(F(1134)=0.13$, $\left.\mathrm{p}=.72, \eta_{p}^{2}=.001\right)$, the overall final exam $(\mathrm{F}(1134)=0.89, \mathrm{p}=.35$, $\left.\eta_{p}^{2}=.007\right)$, or overall performance in the course $(\mathrm{F}(1134)=1.92$, $\left.\mathrm{p}=.17, \eta_{p}^{2}=.014\right)$. Inclusion of course cohort in the analysis resulted in no significant main effects of cohort or interactions of cohort with group $(p=.14-.95)$.

\subsection{Experimental manipulation}

A 2-Group by 3-Lecture Day mixed ANOVA was used to analyze retention performance for the manipulated lecture material. The main effect of Lecture Day was not significant, $F(2268)=2.71, p=.069$, $\eta_{p}^{2}=.020$, nor was the main effect of Group, $\mathrm{F}(1134)=3.41, \mathrm{p}=.067$, $\eta_{p}^{2}=.025$, although Day 2 tended to have generally higher scores than other days and the experimental group scored somewhat better than the control group. There was a significant Group by Lecture Day interaction, $\mathrm{F}(2268)=3.79, \mathrm{p}<.024, \eta_{p}^{2}=.028$. Experimental participants answered more questions from Day 2 correctly than did Control participants, $\mathrm{F}(1134)=10.8, \mathrm{p}=.001, \eta_{p}^{2}=.075$; other contrasts were not significant, Day $1: \mathrm{F}(1134)=0.22, \mathrm{p}=.64$, $\eta_{p}^{2}=.002$; Day 3: $\mathrm{F}(1134)=0.01, \mathrm{p}=.92, \eta_{p}^{2}=.00$. The results are shown in Fig. 1. Inclusion of cohort as a variable in the analysis produced no significant effects involving cohort $(p=.13-.77)$. 


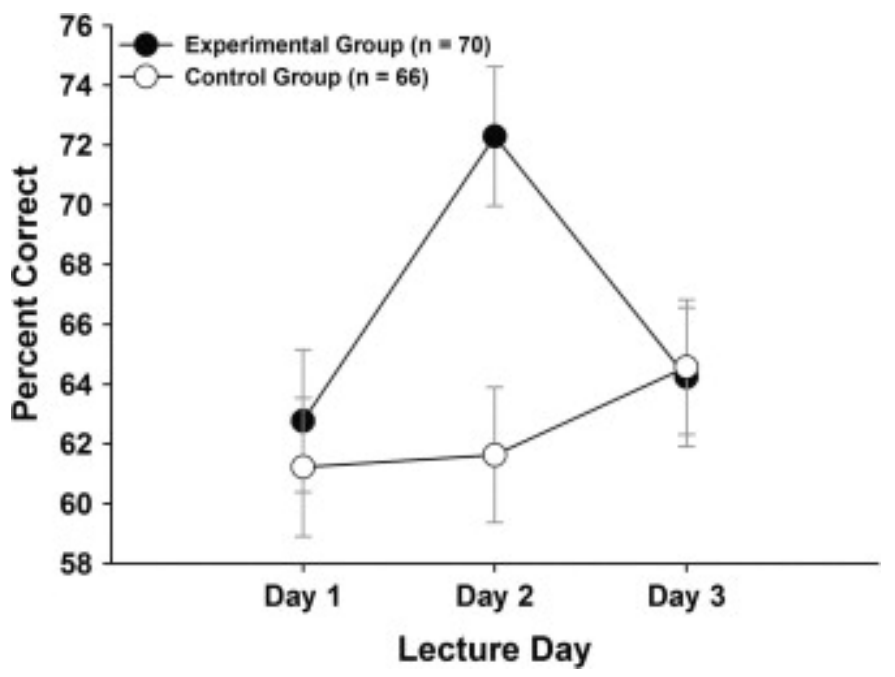

Fig. 1. Percent correct recognition performance for the seven final examination items relevant to each of the three lecture days included in the present study, separated by participant group. Day 2 was followed by an arousing video in the experimental group and by a documentary video in the control group. The examination occurred two weeks later. The experimental group answered significantly more questions correctly for Day 2 material than did the control group. There were no group differences for material from the preceding or succeeding lecture days, or for the first exam, the final exam overall, or total points in the course (see Table 1).

\section{Discussion}

The effect of inducing post-lecture arousal on later exam performance was examined in the current study. After lecture, students were randomly assigned to one of two groups - one that viewed a documentary film clip about cardiovascular health and one that viewed a live-action oral surgery film clip. Participants who viewed the arousal clip rated their arousal higher than those who viewed the neutral clip. Moreover, post-learning arousal specifically enhanced long-term delayed retention for the course material covered immediately prior to the manipulation, relative to other course material. Test performance for material presented in the lecture prior to or subsequent to the experimental manipulation did not differ between groups. Furthermore, the neutral video was rated as more interesting than the arousal video, but Fig. 1 clearly shows that the arousal group had better delayed retention performance for the manipulated lecture versus other lectures, while the neutral group did not differ between lectures. Additionally, overall class performance, midterm exam performance, and final exam performance did not 
significantly differ between groups. That is, the arousal manipulation produced a very specific enhancement effect for the material taught just prior to it. Notably, no specific semantic relationship existed between either the control or experimental stimuli and course materials. The current study supports previous studies showing that post-learning arousal improves long-term memory performance (e.g., Nielson \& Bryant, 2005; Nielson \& Jensen, 1994; Nielson \& Lorber, 2009; Nielson \& Meltzer, 2009; Nielson \& Powless, 2007; Nielson et al., 1996, 2005), and extends them for the first time to a real-world memory context.

Examining the effects of memory modulation in an applied context theoretically introduced more variability than traditional laboratory experiments. For instance, there was no way to control the amount of rehearsal, rumination, study time or other study techniques that participants employed between the experimental induction and the final exam. Furthermore, the learned information was available for students to access both before and after the lectures. As such, it is possible that students who saw the arousal video engaged in more or more effective study of the class material from the manipulated lecture than did control participants. This possibility must be investigated in future studies.

A recent study suggested that memory enhancement for emotionally laden material occurred through a combination of increased spontaneous recollections (i.e., rumination) for emotional material and increased subjective emotional arousal in response to the stimuli (Ferree \& Cahill, 2009). Thus, it is possible that memory for lecture materials was enhanced due to increased rumination about it, caused either directly or indirectly by the post-learning surgical film clip. Alternatively, studies in animal models and humans have suggested that post-learning arousal manipulations initiate a series of neuromodulatory mechanisms that enhance the consolidation of the recently learned material (cf. McGaugh, 2000, 2004). Whether these mechanisms lead to increased rumination or whether these may be parallel and complementary mechanisms remains to be clarified in future research. Moreover, the very specific enhancement of exam performance for material subjected to post-learning arousal, despite the ad lib access to all course materials before and after the manipulation suggests the post-learning arousal approach sets

Neurobiology of Learning and Memory, Vol 98, No. 1 (July 2012): pg. 12-16. DOI. This article is @ Elsevier and permission has been granted for this version to appear in e-Publications@Marquette. Elsevier does not grant permission for this article to be further copied/distributed or hosted elsewhere without the express permission from Elsevier. 
memory modulatory processes into motion may be resistant to general interfering factors that might occur later in time. Future studies need to directly test this possibility.

Post-learning arousal could potentially enhance student learning in several ways. Most previously employed strategies targeted at enhancing student learning influence only to the material specifically targeted. For instance, mnemonic strategies can assist the retention of information, but they must be directly linked to and tailored for specific memoranda (Levin \& Levin, 1990). Retention can also be enhanced by instructors who use inferential questions during lecture (van den Broek, Tzeng, Risden, Trabasso, \& Basche, 2001) and the use of active learning tasks during class (Biazak, Marley, \& Levin, 2010), but these techniques must be closely tailored to the information to be learned. Thus, teachers' and pupils' strategies must be tailored to the information. While such approaches are valuable and effective, post-learning arousal could also be valuable, possibly useful in any learning context and to influence any type of declarative learning. Importantly, the instructor can use the approach without awareness or action on the part of the student. Finally, post-learning arousal might have additive effects when combined with other encoding- and retrieval-related strategies, which future studies should investigate.

Notably, the current study employed a decidedly negative arousal stimulus. By design, the oral surgery video provoked strong ratings of displeasure and disgust from those who viewed it. While such a stimulus was effective, it might not be desirable to use such a stimulus in classrooms or other contexts. Importantly, in previous laboratory experiments, small unexpected rewards given soon after learning have had memory enhancing effects (Nielson \& Bryant, 2005) and a humorous video clip (e.g., Saturday Night Live) was shown to have equally effective memory enhancing qualities when viewed after learning as the surgery video (Nielson \& Powless, 2007). Various studies have suggested that students learn and retain information better from instructors who judiciously use humor, with various hypotheses postulated to account for the findings (Wanzer, Frymier, \& Irwin, 2010). It is just as possible that the arousal evoked in response to instructor humor underlies the learning effect, but this has not yet been empirically evaluated.

Neurobiology of Learning and Memory, Vol 98, No. 1 (July 2012): pg. 12-16. DOI. This article is @ Elsevier and permission has been granted for this version to appear in e-Publications@Marquette. Elsevier does not grant permission for this article to be further copied/distributed or hosted elsewhere without the express permission from Elsevier. 
Although post-learning arousal was effective to enhance retention in the current study, it is not yet known if the technique would be effective with repeated use, such as across multiple lectures or an entire semester. It is also not known whether the subject matter or type of test would influence the effect. Only multiple choice testing (i.e., recognition memory rather than recall) was employed in the current study. Although in rodent studies, all forms of learning have been shown to be susceptible to modulation, human studies have thus far been far more limited in scope. For example, post-learning arousal has not yet been evaluated with non-declarative learning (e.g., skills) or with performance-based outcome measures in humans. Clearly, more forms of memory and modulation approaches need to be investigated to determine the precise effects, mechanisms and relevant covariates in humans. Some recent studies have shown individual differences in the efficacy of post-learning arousal, including such factors as arousal predisposition and emotion regulation strategy tendencies (Nielson \& Lorber, 2009). Finally, the sample in the current study was predominantly female (as is common across upper division psychology courses). There have been demonstrations of sex differences in memory modulation, particularly pursuant to glucocorticoids and sex hormones, that may contribute to studies such as the current one (cf. Cahill, 2006; Ertman, Andreano, \& Cahill, 2001). Such factors, as well as the role of student academic aptitude or limitations, should be evaluated in future efficacy studies for memory modulation in applied contexts.

\section{Acknowledgements}

The authors appreciate the assistance of Michelle Schoenleber on earlier stages of this project. This work was supported in part by Marquette University.

\section{References}

Adolphs et al., 2005. R. Adolphs, D. Tranel, T.W. Buchanan. Amygdala damage impairs emotional memory for gist but not details of complex stimuli. Nature Neuroscience, 8 (4) (2005), pp. 512-518

Atkinson et al., 1999. R.K. Atkinson, J.R. Levin, K.A. Kiewra, T. Meyers, S.-I. Kim, L.A. Atkinson, et al. Matrix and mnemonic text-processing adjuncts: Comparing and combining their components. Journal of Educational Psychology, 91 (2) (1999), pp. 342-357

Neurobiology of Learning and Memory, Vol 98, No. 1 (July 2012): pg. 12-16. DOI. This article is @ Elsevier and permission has been granted for this version to appear in e-Publications@Marquette. Elsevier does not grant permission for this article to be further copied/distributed or hosted elsewhere without the express permission from Elsevier. 
Biazak et al., 2010. J.E. Biazak, S.C. Marley, J.R. Levin. Does an activitybased learning strategy improve preschool children's memory for narrative passages? Early Childhood Research Quarterly, 25 (4) (2010), pp. 515-526

Butler and Roediger, 2007. A.C. Butler, H.L. Roediger. Testing improves longterm retention in a simulated classroom setting. European J ournal of Cognitive Psychology, 19 (4/5) (2007), pp. 514-527

Cahill, 2006. L. Cahill. Why sex matters for neuroscience. Nature Reviews Neuroscience, 7 (2006), pp. 477-484

Cahill and Alkire, 2003. L. Cahill, M.T. Alkire. Epinephrine enhancement of human memory consolidation: Interaction with arousal at encoding. Neurobiology of Learning and Memory, 79 (2) (2003), pp. 194-198

Cahill et al., 2003. L. Cahill, L. Gorski, K. Le. Enhanced human memory consolidation with post-learning stress: Interaction with the degree of arousal at encoding. Learning and Memory, 10 (4) (2003), pp. 270274

Canli et al., 2000. T. Canli, Z. Zhao, J. Brewer, J.D.E. Gabrieli, L. Cahill. Event-related activation in the human amygdala associates with later memory for individual emotional experience. Journal of Neuroscience, 20 (19) (2000), p. RC99

Carney and Levin, 2002. R.N. Carney, J.R. Levin. Coming to terms with the keyword method in introductory psychology: A 'neuromnemonic' example. R.A. Griggs (Ed.), Handbook for teaching introductory psychology: Vol. 3. With an emphasis on assessment, Lawrence Erlbaum, Mahwah, NJ (2002), pp. 225-227

Cassaday et al., 2002. H.J . Cassaday, R.E. Bloomfield, N. Hayward. Relaxed conditions can provide memory cues in both undergraduates and primary school children. British J ournal of Educational Psychology, 72 (4) (2002), pp. 531-547

Cherney, 2008. I.D. Cherney. The effects of active learning on students' memories for course content. Active Learning in Higher Education, 9

(2) (2008), pp. 152-171

Colrain et al., 1992. I.M. Colrain, G.L. Mangan, O.L. Pellett, T.C. Bates. Effects of post-learning smoking on memory consolidation.

Psychopharmacology, 108 (4) (1992), pp. 448-451

Cooper et al., 2001. G. Cooper, S. Tindall-Ford, P. Chandler, J. Sweller. Learning by imagining. Journal of Experimental Psychology, 7 (1) (2001), pp. 68-82

Czech et al., 2000. D.A. Czech, K.A. Nielson, K.K. Laubmeier. Chronic administration of propranolol impairs Morris water maze retention in the mouse. Neurobiology of Learning and Memory, 17 (2000), pp. 1726

Neurobiology of Learning and Memory, Vol 98, No. 1 (July 2012): pg. 12-16. DOI. This article is @ Elsevier and permission has been granted for this version to appear in e-Publications@Marquette. Elsevier does not grant permission for this article to be further copied/distributed or hosted elsewhere without the express permission from Elsevier. 
NOT THE PUBLISHED VERSION; this is the author's final, peer-reviewed manuscript. The published version may be

accessed by following the link in the citation at the bottom of the page.

Dickerson and Kemeny, 2004. S.S. Dickerson, M.E. Kemeny. Acute stressors and cortisol responses: A theoretical integration and synthesis of laboratory research. Psychological Bulletin, 130 (3) (2004), pp. 355391

Dretzke, 1993. B.J. Dretzke. Effects of pictorial mnemonic strategy usage on prose recall of young, middle-aged, and older adults. Educational Gerontology, 19 (6) (1993), pp. 489-502

Ertman et al., 2011. N. Ertman, J.M. Andreano, L. Cahill. Progesterone at encoding predicts subsequent emotional memory. Learning and Memory, 18 (2011), pp. 759-763

Ferree and Cahill, 2009. N.K. Ferree, L. Cahill. Post-event spontaneous intrusive recollections and strength of memory for emotional events in men and women. Consciousness and Cognition, 18 (1) (2009), pp. 126-134

Gold and van Buskirk, 1975. P.E. Gold, R.B. van Buskirk. Facilitation of timedependent memory processes with posttrial epinephrine injections. Behavioral Biology, 13 (2) (1975), pp. 145-153

Johnson and Johnson, 1983. D.W. Johnson, R.T. Johnson. Social interdependence and perceived academic and personal support in the classroom. Journal of Social Psychology, 120 (1) (1983), pp. 77-82

Kensinger and Corkin, 2004. E.A. Kensinger, S. Corkin. Two routes to emotional memory: Distinct neural processes for valence and arousal. Proceedings of the National Academy of Sciences of the United States of America, 101 (9) (2004), pp. 3310-3315

Kleinsmith and Kaplan, 1963. L.J. Kleinsmith, S. Kaplan. Paired-associate learning as a function of arousal and interpolated interval. Journal of Experimental Psychology, 65 (2) (1963), pp. 190-193

Kobayashi, 2006. K. Kobayashi. Combined effects of note-taking/-reviewing on learning and the enhancement through interventions: A metaanalytic review. Educational Psychology, 26 (3) (2006), pp. 459-477

LaBar and Cabeza, 2006. K.S. LaBar, R. Cabeza. Cognitive neuroscience of emotional memory. Nature Reviews Neuroscience, 7 (1) (2006), pp. 54-64

Leahy and Sweller, 2005. W. Leahy, J. Sweller. Interactions among the imagination, expertise reversal, and element interactivity effects. Journal of Experimental Psychology: Applied, 11 (4) (2005), pp. $266-$ 276

Levin and Levin, 1990. M.E. Levin, J.R. Levin. Scientific mnemonomies: Methods for maximizing more than memory. American Educational Research Journal, 27 (2) (1990), pp. 301-321

Manning et al., 1992. C.A. Manning, M.W. Parsons, P.E. Gold. Anterograde and retrograde enhancement of 24-h memory by glucose in elderly humans. Behavioral and Neural Biology, 58 (2) (1992), pp. 125-130

Neurobiology of Learning and Memory, Vol 98, No. 1 (July 2012): pg. 12-16. DOI. This article is @ Elsevier and permission has been granted for this version to appear in e-Publications@Marquette. Elsevier does not grant permission for this article to be further copied/distributed or hosted elsewhere without the express permission from Elsevier. 
McCarty and Gold, 1981. R. McCarty, P.E. Gold. Plasma catecholamines: Effects of footshock level and hormonal modulators of memory storage. Hormones and Behavior, 15 (2) (1981), pp. 168-182

McGaugh, 1966. J.L. McGaugh. Time-dependent processes in memory storage. Science, 153 (3742) (1966), pp. 1351-1358

McGaugh, 1990. J.L. McGaugh. Significance and remembrance. The role of neuromodulatory systems, Psychological Science, 1 (1) (1990), pp. $15-25$

McGaugh, 2000. J.L. McGaugh. Memory - A century of consolidation. Science, 287 (5451) (2000), pp. 248-251

McGaugh, 2004. J.L. McGaugh. The amygdala modulates the consolidation of memories of emotionally arousing experiences. Annual Review of Neuroscience, 27 (2004), pp. 1-28

Merali et al., 1998. Z. Merali, J. Mcl ntosh, P. Kent, D. Michaud, H. Anisman. Aversive and appetitive events evoke the release of corticotropinreleasing hormone and bombesin-like peptides at the central nucleus of the amygdala. The Journal of Neuroscience, 18 (12) (1998), pp. 4758-4766

Metzger et al., 1979. R.L. Metzger, P.F. Boschee, T. Haugen, B.L. Schnobrich. The classroom as learning context: Changing rooms affects performance. Journal of Educational Psychology, 71 (4) (1979), pp. 440-442

Nastasi and Clements, 1991. B.K. Nastasi, D.H. Clements. Research on cooperative learning: Implications for practice. School Psychology Review, 20 (1) (1991), pp. 110-131

Nielson and Bryant, 2005. K.A. Nielson, T. Bryant. The effects of noncontingent extrinsic and intrinsic rewards on memory consolidation. Neurobiology of Learning and Memory, 84 (2005), pp. 42-48

Nielson et al., 1999. K.A. Nielson, D.A. Czech, K.K. Laubmeier. Chronic administration of propranolol impairs inhibitory avoidance retention in the mouse. Neurobiology of Learning and Memory, 71 (1999), pp. 248-257

Nielson and Jensen, 1994. K.A. Nielson, R.A. Jensen. Beta-adrenergic receptor antagonist antihypertensive medications impair arousalinduced modulation of working memory in elderly humans. Behavioral and Neural Biology, 63 (3) (1994), pp. 190-200

Nielson and Lorber, 2009. K.A. Nielson, W. Lorber. Enhanced post-learning memory consolidation is influenced by arousal predisposition and emotion regulation but not by stimulus valence or arousal. Neurobiology of Learning and Memory, 92 (2009), pp. 70-79 Nielson and Meltzer, 2009. K.A. Nielson, M.A. Meltzer. Modulation of longterm memory by arousal in alexithymia: The role of interpretation. Consciousness and Cognition, 18 (2009), pp. 786-793

Neurobiology of Learning and Memory, Vol 98, No. 1 (July 2012): pg. 12-16. DOI. This article is @ Elsevier and permission has been granted for this version to appear in e-Publications@Marquette. Elsevier does not grant permission for this article to be further copied/distributed or hosted elsewhere without the express permission from Elsevier. 
Nielson and Powless, 2007. K.A. Nielson, M. Powless. Positive and negative sources of emotional arousal enhance long-term word-list retention when induced as long as $30 \mathrm{~min}$ after learning. Neurobiology of Learning and Memory, 88 (2007), pp. 40-47

Nielson et al., 1996. K.A. Nielson, R.C. Radtke, R.A. Jensen. Arousal-induced modulation of memory storage processes in humans. Neurobiology of Learning and Memory, 66 (2) (1996), pp. 133-142

Nielson et al., 2005. K.A. Nielson, D. Yee, K.I. Erickson. Memory enhancement by a semantically unrelated emotional arousal source induced after learning. Neurobiology of Learning and Memory, 84 (2005), pp. 49-56

Peters and Levin, 1986. E.E. Peters, J.R. Levin. Effects of a mnemonic imagery strategy on good and poor readers' prose recall. Reading Research Quarterly, 21 (2) (1986), pp. 179-192

Piazza and Le Moal, 1997. P.V. Piazza, M. Le Moal. Glucocorticoids as a biological substrate of reward: Physiological and pathophysiological implications. Brain Research - Brain Research Reviews, 25 (3) (1997), pp. 359-372

Reutzel and Hollingsworth, 1988. D. R. Reutzel, P.M. Hollingsworth. Highlighting key vocabulary: A generative-reciprocal procedure for teaching selected inference types. Reading Research Quarterly, 23 (3) (1988), pp. 358-378

Revelle and Loftus, 1992. W. Revelle, D.A. Loftus. The implications of arousal effects for the study of affect and memory. S.-Å. Christianson (Ed.), The handbook of emotion and memory, Lawrence Erlbaum Association, Hillsdale, NJ, England (1992), pp. 113-150

Rickards and McCormick, 1988. J.P. Rickards, C.B. McCormick. Effect of interspersed conceptual prequestions on note-taking in listening comprehension. Journal of Educational Psychology, 80 (4) (1988), pp. 592-594

Rummel et al., 2003. N. Rummel, J.R. Levin, M. M. Woodward. Do pictorial mnemonic text-learning aids give students something worth writing about? Journal of Educational Psychology, 95 (2) (2003), pp. 327-334

Southwick et al., 2002. S.M. Southwick, M. Davis, B. Horner, L. Cahill, C.A. Morgan, P.E. Gold, et al. Relationship of enhanced norepinephrine activity during memory consolidation to enhanced long-term memory in humans. American J ournal of Psychiatry, 159 (8) (2002), pp. 14201422

Squire, 1986. L.S. Squire. Mechanisms of memory. Science, 232 (4758) (1986), pp. 1612-1619

Torras-Garcia et al., 1997. M. Torras-Garcia, I. Portell-Cortés, D. CostaMiserachs, I. Morgado-Bernal. Long-term memory modulation by posttraining epinephrine in rats: Differential effects depending on the

Neurobiology of Learning and Memory, Vol 98, No. 1 (July 2012): pg. 12-16. DOI. This article is @ Elsevier and permission has been granted for this version to appear in e-Publications@Marquette. Elsevier does not grant permission for this article to be further copied/distributed or hosted elsewhere without the express permission from Elsevier. 
NOT THE PUBLISHED VERSION; this is the author's final, peer-reviewed manuscript. The published version may be accessed by following the link in the citation at the bottom of the page.

basic learning capacity. Behavioral Neuroscience, 111 (2) (1997), pp. 301-308

van den Broek et al., 2001. P. van den Broek, Y. Tzeng, K. Risden, T. Trabasso, P. Basche. Inferential questioning: Effects on comprehension of narrative texts as a function of grade and timing. Journal of Educational Psychology, 93 (3) (2001), pp. 521-529

van Stegeren et al., 1998. A.H. van Stegeren, W. Everaerd, L. Cahill, J.L. McGaugh, L.J.G. Gooren. Memory for emotional events: Differential effects of centrally versus peripherally acting $\beta$-blocking agents. Psychopharmacology, 138 (3-4) (1998), pp. 305-310

Walker, 1958. E.L. Walker. Action decrement and its relation to learning. Psychological Review, 65 (3) (1958), pp. 129-142

Wanzer et al., 2010. M.B. Wanzer, A.B. Frymier, J. Irwin. An explanation of the relationship between instructor humor and student learning: Instructional humor processing theory. Communication Education, 59 (1) (2010), pp. 1-18

Willingham, 2008. D.T. Willingham. Ask the cognitive scientist: What will improve a student's memory? American Educator, 32 (4) (2008), pp. $17-25,44$

Neurobiology of Learning and Memory, Vol 98, No. 1 (July 2012): pg. 12-16. DOI. This article is @ Elsevier and permission has been granted for this version to appear in e-Publications@Marquette. Elsevier does not grant permission for this article to be further copied/distributed or hosted elsewhere without the express permission from Elsevier. 